\title{
Radiofrequency Ablation of Osteoid Osteomas: Analgesia and Patient Satisfaction in Long-term Follow-up
}

\section{Radiofrequenzablation von Osteoidosteomen: Schmerz- freiheit und Patientenzufriedenheit im Langzeitverlauf}

Authors

Affiliations
B. Gebauer ${ }^{1}$, F. Collettini' ${ }^{1}$, C. Bruger ${ }^{1}$, K.-D. Schaser ${ }^{2}$, I. Melcher ${ }^{2}$, P.-U. Tunn ${ }^{3}$, F. Streitparth

Department of Radiology, Charité - Universitätsmedizin Berlin

Center for Musculoskeletal Surgery, Charité - Universitätsmedizin Berlin

3 Department of Orthopaedic Oncology, HELIOS-Klinikum Berlin-Buch
Key words

- ablation procedures

- radiofrequency ablation

- osteoid osteoma

- complication

- patient satisfaction eingereicht 8.1.2013

akzeptiert 1.7.2013

Bibliography

DOI http://dx.doi.org/

10.1055/s-0033-1350347

Published online: 23.8.2013

Fortschr Röntgenstr 2013; 185:

959-966 ๑ Georg Thieme

Verlag KG Stuttgart · New York . ISSN 1438-9029

\section{Correspondence}

Herr Prof. Bernhard Gebauer Klinik für Strahlenheilkunde, Charité - Universitätsmedizin Augustenburger Platz 1 13353 Berlin

Tel.: ++49/30/450557001

Fax: ++ 49/30/450557901

bernhard.gebauer@charite.de

\section{Abstract}

$\nabla$

Purpose: To review the long term clinical outcomes in the treatment of osteoid osteoma (OO) using radiofrequency ablation (RFA). Materials and Methods: Our retrospective study included 59 patients who were treated in the period from April 2001 to December 2012 due to a symptomatic OO using RFA. Here, the occurrence of complications and postoperative recurrence, as well as postoperative patient satisfaction were examined. Patients satisfaction was assessed by means of a telephone interview with the visual analogue scale (VAS).

Results: Mean follow-up was 50 months (2 116 months). The average size of the nidus was $6 \mathrm{~mm}$ (range 2-14 mm). After initial radiofrequency ablation $11.8 \%$ (7/59) of patient showed a recurrence of symptoms. Symptoms could successfully be treated by a second ablation in 5 patients. Assisted success rate was therefore $96.6 \%$ (57/59). The complication rate was $5.1 \%$ (2 major and one minor complication). Furthermore we report a very high patient satisfaction and acceptance of therapy.

Conclusion: RFA is a very successful therapy of symptomatic OOs with a high patient satisfaction.

Key Points:

- Osteoid osteomas (OO) are rare benign bone tumors of the childhood and adolescence.

- Treatment of OOs with minimal-invasive radiofrequency ablation (RFA) shows a high patient satisfaction.

- RFA is by now the standard therapy of symptomatic OOs.
Citation Format:

- Gebauer B, Collettini F, Bruger C etal. Radiofrequency Ablation of Osteoid Osteomas: Analgesia and Patient Satisfaction in Long-term Follow-up. Fortschr Röntgenstr 2013; 185: 959-966

\section{Zusammenfassung \\ $\nabla$}

Ziel: Ermittlung des klinischen Erfolgs und der Patientenzufriedenheit nach Radiofrequenzablation (RFA) von symptomatischen Osteoidosteomen (OO) im Langzeitverlauf.

Material und Methoden: Unsere retrospektive Studie umfasste 59 Patienten, die im Zeitraum von April 2001 bis Dezember 2012 aufgrund eines symptomatischen 00 mittels RFA behandelt wurden. Dabei wurden Rezidive und Komplikationen sowie die postinterventionelle Patientenzufriedenheit ermittelt. Die Patientenzufriedenheit und der Restschmerz (visuelle Analogskala [VAS]) wurden mittels eines standardisierten Telefoninterviews ermittelt.

Ergebnisse: Der Nachbeobachtungszeitraum erstreckte sich im Durchschnitt über 50 Monate (2-116 Monate). Die durchschnittliche Größe des Nidus lag bei $6 \mathrm{~mm}(2-14 \mathrm{~mm})$. Die initiale Radiofrequenzablation zeigte in $11,8 \%$ (7/59) ein Rezidiv der Schmerzsymptomatik, das bei $5 \mathrm{~Pa}$ tienten mittels einer zweiten Ablation erfolgreich behandelt werden konnte. Die assistierte Erfolgsrate war somit 96,6\% (57/59). Die Komplikationsrate lag bei 5,1\% (2 Major- und eine Minor-Komplikation). Darüber hinaus konnten wir eine sehr hohe Patientenzufriedenheit und Therapieakzeptanz feststellen.

Schlussfolgerung: Die RFA ist ein sehr erfolgreiches Therapieverfahren von symptomatischen Osteoidosteomen mit hoher Patientenzufriedenheit. 


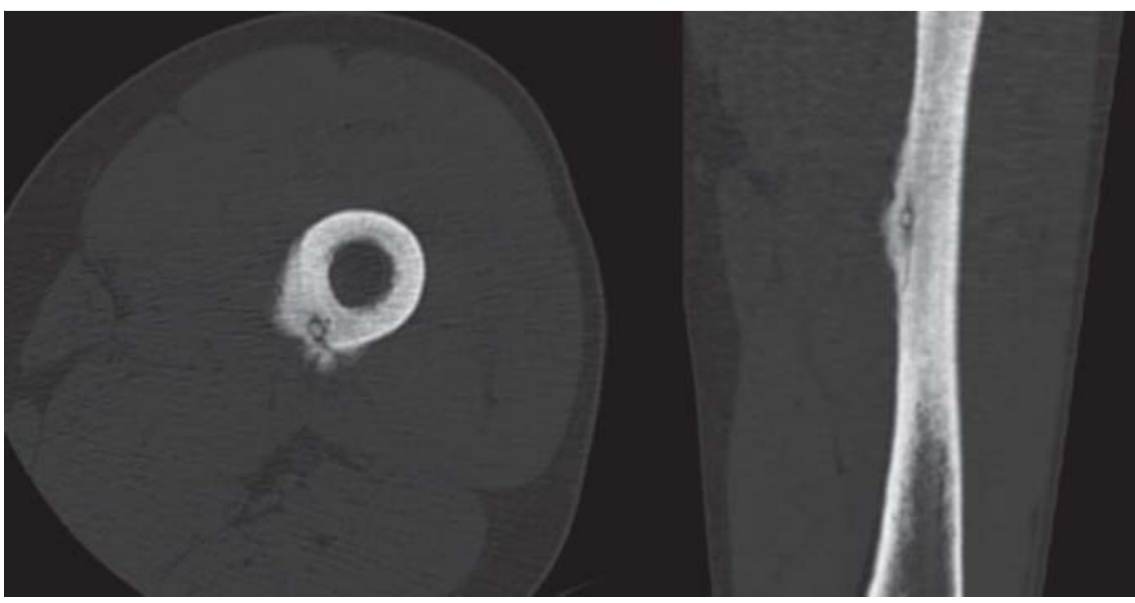

Fig. 1 Typical computed tomographic appearance of a cortical osteoid osteoma of the left femur with central nidus and surrounding reactive bone hypertrophy. The example here exhibits a radiopaque center within the nidus as a correlate for calcification of tumor matrix, which is not present in all osteoid osteomas. A small hypodense line that runs to the nidus is referred to as " $\mathrm{CT}$ vessel sign" or "vascular groove" and regarded as typical for an osteoid osteoma $[9,10]$.

\section{Introduction \\ $\nabla$}

Osteoid osteoma is a benign, osteogenic bone tumor that appears primarily in young patients in their $20 \mathrm{~s}$ and $30 \mathrm{~s}$ [1]. The nidus of the osteoid osteoma consists of immature bone and is rich in blood vessels and nerve cells. These nerve cells produce prostaglandins, in particular prostaglandin E2, presumably causing the characteristic nocturnal pains, which respond rapidly - within 20 to 30 minutes - to non-steroidal anti-inflammatory drugs (NSAIDS) [2].

Characteristic radiological signs of osteoid osteoma are the central, radiotransparent, partly ossifying nidus measuring a maximum of 15 to 20 millimeters and surrounded by a zone of reactive ossification [3].

Left untreated, osteoid osteomas exhibit both clinical and radiological natural regression. However, this process takes on average 6 years (range 2 to 15 years) $[1,4,5]$. NSAIDS not only alleviate the symptoms in patients with osteoid osteoma, but also accelerate the clinical regression of the symptoms to an average of 33 months (range 30 to 40 months) [6].

While the standard therapy for symptomatic osteoid osteoma used to be open resection of the nidus, in the last two decades thermal ablation of the nidus has steadily established itself as the standard therapy since first being described by Rosenthal et al. in 1992 [7, 8].

The present study used a standardized telephone interview to examine the long-term recurrence and complication rates following CT-guided thermoablation (RFA) of symptomatic osteoid osteoma.

\section{Material and methods \\ $\nabla$}

\section{Patients}

The study included all consecutive patients who had been treated between April 2001 and December 2012. Standard imaging prior to therapy consisted of a conventional X-ray in two projections and non-contrast computed tomography (CT). For patients presenting the classic clinical and radiological criteria of an osteoid osteoma (age; nocturnal pains; rapid response to NSAIDs; sharply demarcated, cortical lytic lesion measuring a maximum of $20 \mathrm{~mm}$ in diameter, occasionally exhibiting central calcification; surrounded by cortical, osseous protrusion caused by ossification with soft tis- sue reaction, „CT vessel sign” or „vascular groove sign”) additional imaging or histological confirmations were not performed ( $\bullet$ Fig. 1$)[9,10]$. Patients not satisfying these criteria either underwent additional imaging (contrast-enhanced magnetic resonance imaging (MRI) and/or bone scintigraphy) or had histological confirmation performed immediately prior to the CT-guided ablation.

\section{Interventional therapy}

All patients were informed of the available therapy options as well as the sequence of the intervention and the risks thereof. All ablations were performed under general anesthesia, since the puncture and the ablation of the osteoid osteoma are usually very painful for the patients. In all but one patient, the nidus was drilled open under CT-fluoroscopy. In this process either a 3-4 mm diameter hole was drilled through the nidus using an electrical orthopedic drill under CT-guidance, or, if the nidus was located at a shallow depth, there was a thin cortical bone layer or histological confirmation was desired, a bone punch biopsy was taken by the radiologist using a hand drill (11 G Präpa-Plus, Pflugbeil, Zorneding, Germany) or a battery-operated bone biopsy system (15G OnControl, VIDACARE, Shavano Park, Tx, USA) ( $\bullet$ Fig. 2). Afterwards, thermal ablation was performed using temperature-controlled radiofrequency ablation (RFA) (16G RITA StarBurst SDE, RITA Medical Systems, Mountain View, USA) with a target temperature of $60-90^{\circ}$ $C$ at a maximum power of 90 Watts for $4-6$ minutes. $<0$ \} The reduced temperature of $60^{\circ} \mathrm{C}$ was used on patients in whom it was absolutely necessary to prevent thermal damage of the surrounding tissue given the proximity to critical neighboring structures (generally nerves). „Low temperature" ablation was used most frequently for ablating osteoid osteomas near the spinal column (० Fig. 3 ).

\section{Post-interventional management}

After undergoing therapy, all patients were monitored while under full inpatient conditions. To check the success of ablation, contrast-enhanced MRI was performed on several patients as well as on any patient in whom recurrence or other complications were suspected.

\section{Telephone interview}

To ascertain the long-term clinical success of the treatment, a standardized telephone survey of all treated patients was 


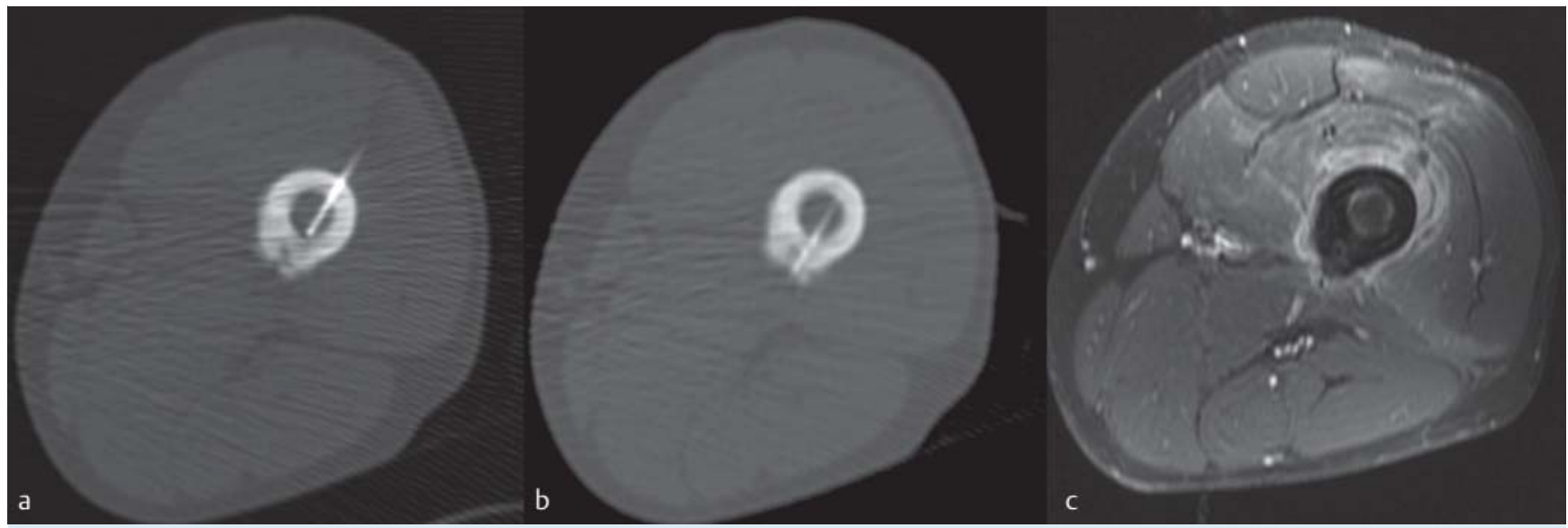

Fig. 2 Successful radiofrequency ablation of an osteoid osteoma with a target temperature of $90^{\circ} \mathrm{C}$ and 6 minutes ablation time a, b. In this case, trans-or bicortical insertion of the applicator through the femoral marrow

space served to protect the posterior neurovascular sheath. Post-interventional MRI 14 days after ablation shows complete devascularization on fat saturated, contrast-enhanced $\mathrm{T} 1$ weighted sequences c.

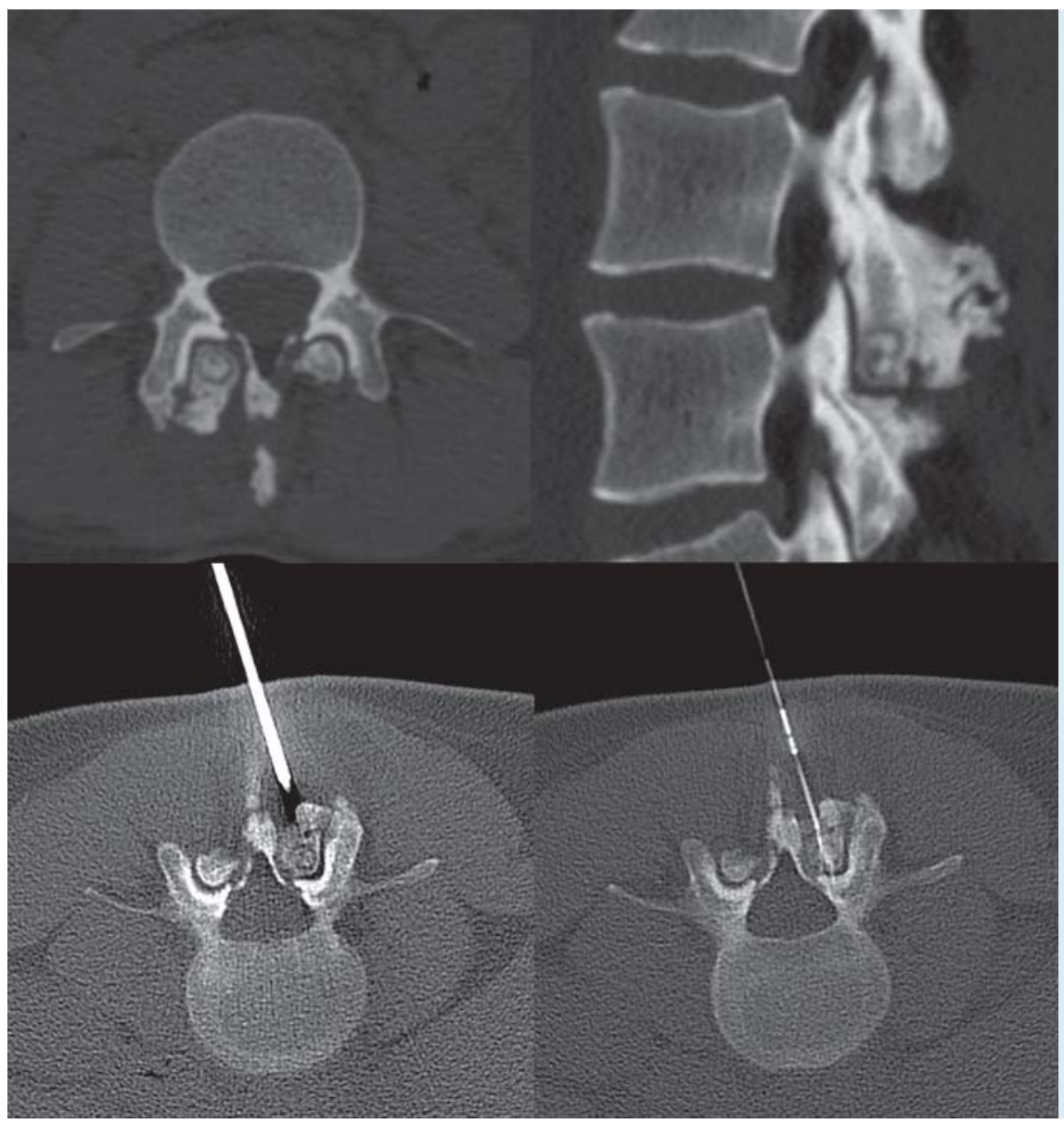

Fig. 3 Radiofrequency ablation of an osteoid osteoma in the right inferior articular process of the $L 3$ vertebra and reactive arthrosis of the adjacent vertebral joint. The patient had chronic back pain for years. CT clearly shows reactive arthrosis of the vertebral joint. CT-guided RFA was successfully performed. The patient has now been pain-free for one year.

conducted between September 2011 and April 2013 (Table 1 ), focusing on the post-therapeutic absence of pain, satisfaction with therapy and subsequent RFA therapy in the case of recurrences.The study and patient survey received ethics approval.

\section{Definitions}

Initial success: Complete subsidence of pain symptoms without the use of anti-inflammatory medication within 1 month; Persisting pain: ongoing typical pain or use of antiinflammatories 1 month following ablation; Recurrence: reappearance of typical symptoms following initial absence of pain; Assisted success rate: complete subsidence of typical pain symptoms following repeated ablation. Complications following ablation were classified according to the recommendations of the Society of Interventional Radiology (SIR) as minor- (A and B) and major- (C through F) complications $[11,12]$. 


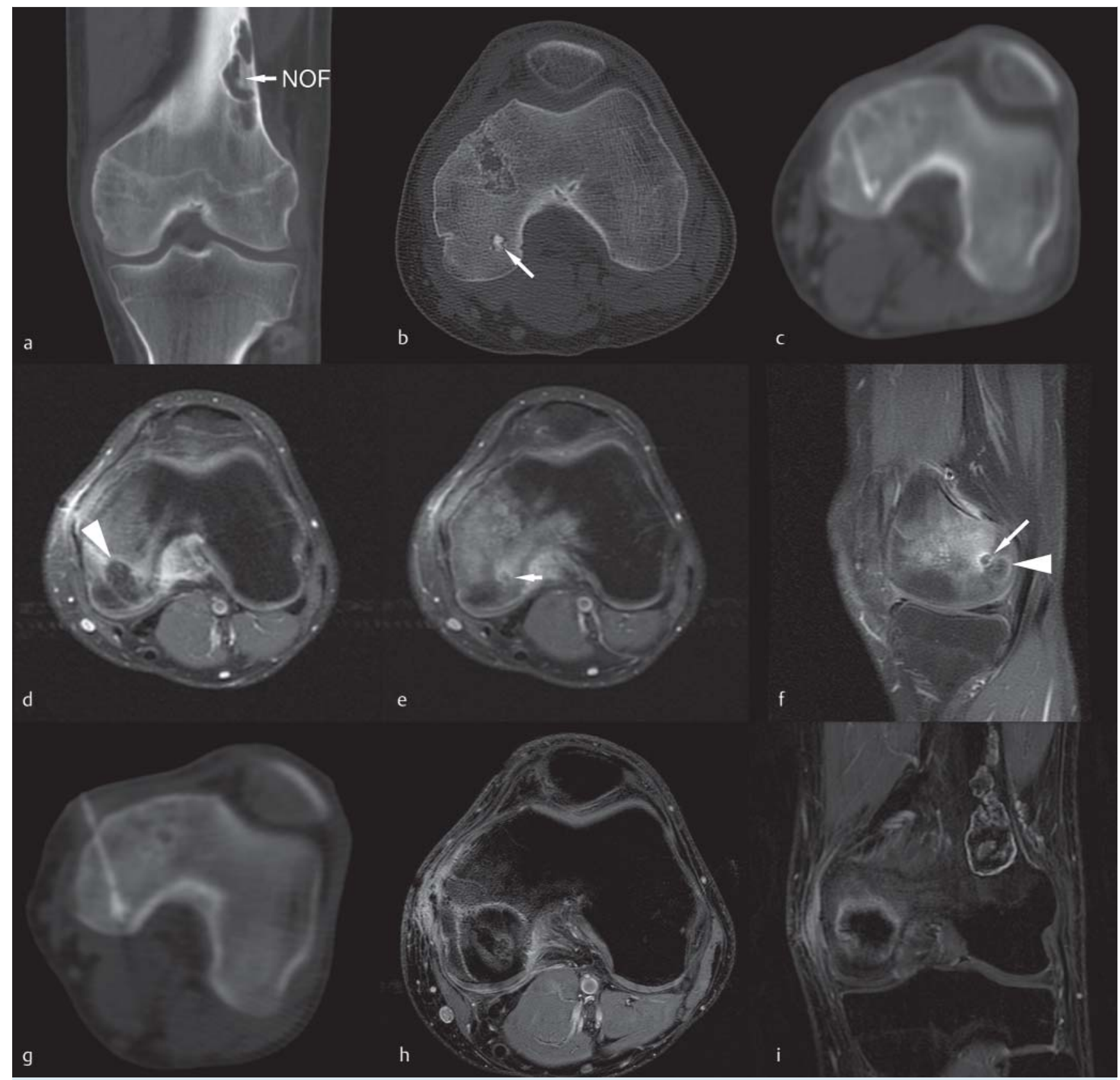

Fig. 4 Recurrence following radiofrequency ablation: small medullary osteoid osteoma (arrow) in the left medial femoral condyle a, b. Puncture and radiofrequency ablation with a reduced target temperature of $60^{\circ} \mathrm{C}$ were performed due to the proximity to the joint surface $\mathbf{c}$. After an initial postinterventional pain-free period, the patient again complained about pain. MRI performed $\mathbf{d}$ recurrent pain 6 weeks after ablation with imaging of an

incomplete ablation in MRI (e, $\mathbf{f}$ ablation zone with recurrent contrast enhancement, arrowhead). Re-ablation was performed with a target temperature of $90^{\circ} \mathrm{C} \mathrm{g}$. Post-interventional MRI shows the ablation zone without enhancement in the nidus after re-ablation $\mathbf{h}$, i. Patient underwent follow-up over a 5 -year period without any recurrence of pain. Secondary finding: non-ossifying fibroma (NOF) of the left lateral femoral metaphysis.

\section{Results}

$\nabla$

\section{Patients}

In the period from April 2001 through December 2012, a total of 59 patients (39 [66\%] male and 20 [34\%] female) were included in the study. At the time of the diagnosis, average patient age was 22 years ( $4-55$ years). The osteoid osteomas were primarily located in the lower extremities in $90 \%$ of cases, with the right femur being the most common location. Also included in the study were 4 patients with symptomatic osteoid osteomas near the spinal column, mainly in the vertebral body. Pre-interventional CT of the osteoid osteomas showed an average nidus diameter of $6 \mathrm{~mm}$ (range: $2-14 \mathrm{~mm}$ ). $<0$ \}

\section{Follow up}

All patients underwent the intervention as an inpatient procedure, (while in theory the intervention could have been performed as an outpatient surgery, it currently cannot be billed as such in German, although it is being discussed). Whenever an ablation was performed on extremely athletic patients (competitive athletes), we recommended 


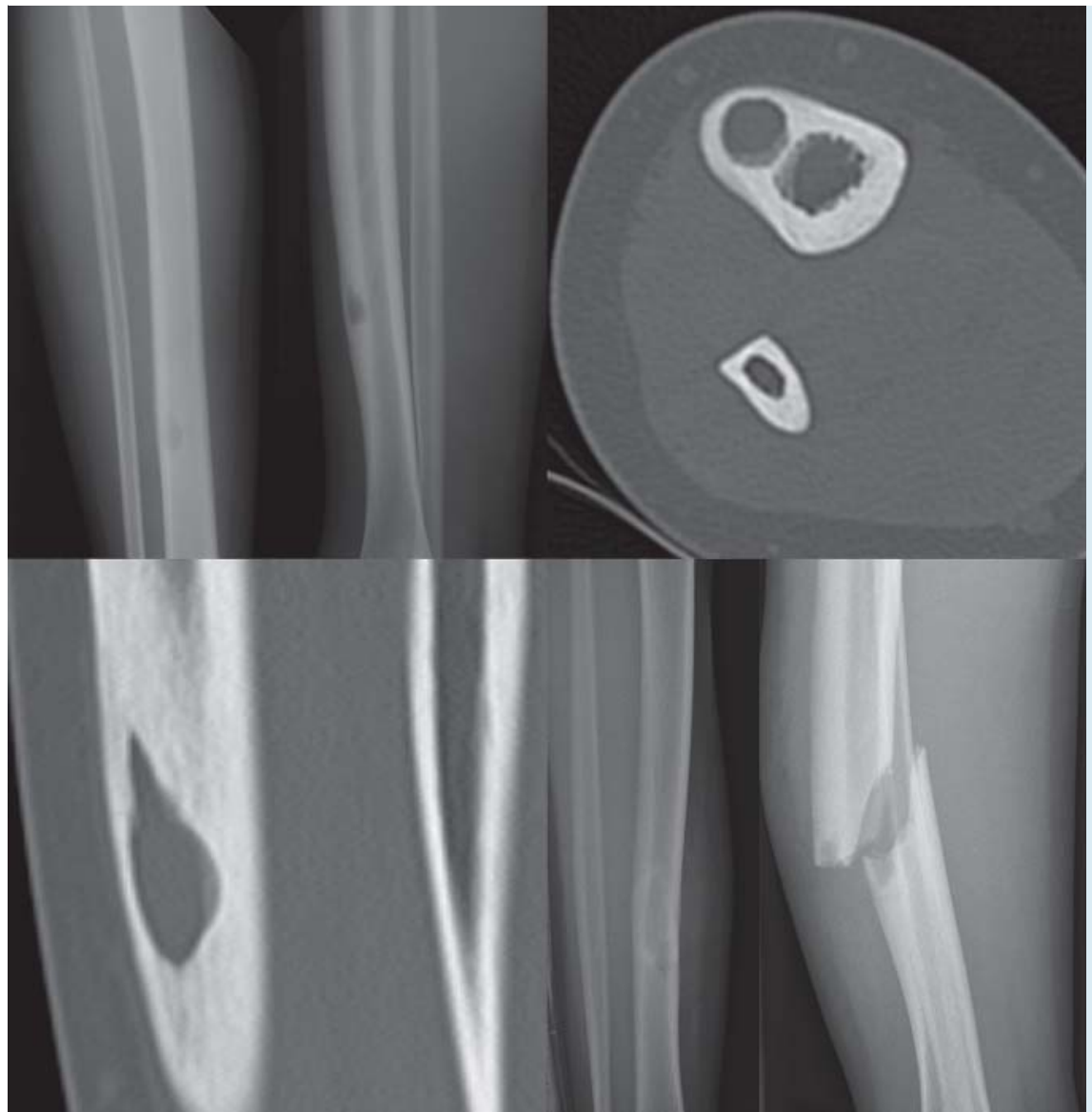

Fig. 5 Tibial fracture in a patient 2 months after successful radiofrequency ablation. The diameter of the osteoid osteoma was $9.5 \mathrm{~mm}$, while the maximum diameter of the tibia of the patient was only $16 \mathrm{~mm}$. The patient was treated with intramedullary nails and a plaster cast.

that they temporarily (approx. 4-6 weeks) restricted themselves from intense athletic activities. While a clinical follow-up examination was performed on all of the patients, medical imaging for the purpose of checking the success of ablation was not routinely performed, since the clinical symptoms of the patients were paramount. The average follow-up since RFA of the osteoid osteoma took place at 50 months (range $2-116$ months).

\section{Technical success}

In all patients, the osteoid osteoma was successfully drilled manually or mechanically and ablated under CT-fluoroscopy during the first therapy session, thus yielding a technical success rate of $100 \%$.

Of 59 patients, 56 were pain-free immediately following ablation as well as during the first month (initial success $=94.9 \%$ ). In the case of 2 patients, further procedure is currently being discussed on an interdisciplinary basis, while in the case of the third patient other causes are presumably responsible for the residual pains. After initially being pain-free, 5 patients experienced a painful recurrence. In all 5 of these patients, contrast MRI performed at the time of the clinical recurrence showed a contrast enhancement in the area of the nidus. All 5 patients were successfully treated with secondary RFA and have remained pain-free long-term ( $\bullet$ Fig.4). Residual pains appearing in any patient were attributed to recurrence of the initial RFA, yielding a total number of recurrences of $n=7$ (11.9\%).

\section{Complications}

One patient presented a soft tissue abscess 3 months following successful ablation, which had to be surgically removed. Two months following RFA, another patient fractured her tibia in the area of the osteoid osteoma when jumping from the horizontal bar during school sports ( $\bullet$ Fig.5). These cases represent two major complications following RFA. A minimal loss of sensitivity in the area of the ablation site was documented in another patient, which later subsided. Thus 3 complications ( 2 major and one minor) were ascertained among the 59 patients, corresponding to a complication rate of $5.1 \%$.

\section{Telephone interview}

The telephone interview was conducted from September 2011 through April 2013. Of the 59 patients, 6 could not be reached by telephone. The results of the telephone interview are summarized in $\bullet$ Table 1 , which reflects a very high level of patient satisfaction and therapy acceptance.

\section{Discussion \\ $\nabla$}

The goal in treating osteoid osteoma is freeing the patient from his or her pain [13]. Traditionally, surgical therapeutic methods (e.g., "en block" resection, curettage) had been long regarded as the gold standard in treatment of osteoid osteoma, since they exhibited very high success rates between 88 and $100 \%$ and had been long established [1417]. The disadvantage of open surgical resection is the dis- 
Table 1 Results of the telephone interview. The interviews were conducted in the period between September 2011 and April 2013.

\begin{tabular}{|c|c|}
\hline $\begin{array}{l}\text { Patients reached through tele- } \\
\text { phone interview }\end{array}$ & $53 / 59(89,8 \%)$ \\
\hline $\begin{array}{l}\text { Time elapsed between RFA abla- } \\
\text { tion and telephone interview }\end{array}$ & $\begin{array}{l}\text { Mean } 50.1 \text { months (range } \\
2-116 \text { months; median: } 56 \\
\text { months) }\end{array}$ \\
\hline Question: & Answers: \\
\hline $\begin{array}{l}\text { Do you remember being treated } \\
\text { by us in the hospital? }\end{array}$ & Yes: 53; No: 0 \\
\hline $\begin{array}{l}\text { Do you remember where the in- } \\
\text { tervention was performed/where } \\
\text { the lesion was located? }\end{array}$ & Yes: 53; No: 0 \\
\hline $\begin{array}{l}\text { Were you satisfied with the ther- } \\
\text { apy/with the treatment? }\end{array}$ & Yes: 53; No: 0 \\
\hline $\begin{array}{l}\text { Have you continued to experience } \\
\text { pain following the therapy? }\end{array}$ & Yes: 3 ; No: 0 \\
\hline $\begin{array}{l}\text { If yes: Were/are the pains at the } \\
\text { same location or at a different } \\
\text { location? }\end{array}$ & $\begin{array}{l}\text { Same location: 3; Different loca- } \\
\text { tion: } 0\end{array}$ \\
\hline $\begin{array}{l}\text { Do you still experience residual } \\
\text { pains? }\end{array}$ & Yes: 4; No: 49 \\
\hline $\begin{array}{l}\text { - If yes, how would you rate it on a } \\
\text { pain scale (VAS } 0-10) ?\end{array}$ & $\begin{array}{l}\text { VAS } 0 \text { (no pain) } 49 \text { patients; VAS } 2 \\
2 \text { patients; VAS } 31 \text { patient; VAS } 8 \\
1 \text { patient }\end{array}$ \\
\hline $\begin{array}{l}\text { - Have you undergone further } \\
\text { treatment for the residual pain? }\end{array}$ & Yes: $0 ;$ No: 4 \\
\hline $\begin{array}{l}\text { Do you suffer from functional } \\
\text { limitations following the therapy? }\end{array}$ & Yes: $1^{1}$; No: 52 \\
\hline $\begin{array}{l}\text { Would you undergo the therapy } \\
\text { again? }\end{array}$ & Yes: 53; No: 0 \\
\hline
\end{tabular}

${ }^{1}$ The patient with fracture of the tibia after RFA (Fig. 5). Interval between fracture and patient interview was 2 months, therefore the patient still had functional limitations.

parity between the relatively small osteoid osteoma and the extent of the necessary resection with the extended functional limitation of the treated skeletal section. The percutaneous resection performed with a drill or a hollow drill (punch) has been described in several studies as an alternative, less invasive surgical method with similar success rates of $84-100 \%[18-20]$.

Over the past few decades it has been demonstrated that thermal ablation of the nerve- and prostaglandin-producing cells in the nidus of the osteoid osteoma is sufficient for treating symptomatic osteoid osteoma. Among thermal methods, radiofrequency ablation (RFA) is the technique that has been studied the best and has the widest clinical use. In the meantime, it has become regarded by many authors and hospitals as the standard therapy for osteoid osteoma.

To date there are numerous positive study results on the treatment of osteoid osteoma using CT-guided RFA. Table $\mathbf{2}$ offers an overview of these study results as well as the appearing complications.

In various studies covering a total of more than 1356 patients, it has been demonstrated that the treatment of osteoid osteoma with RFA yields a success rate of 65 to $100 \%$ following the first ablation with an average initial success rate of $92 \%$.

In our study we achieve a technical success rate of $100 \%$ as well as an initial clinical success rate of $94.2 \%$ ( 2 patients with residual pain [VAS $>2$ ]). All other patients had no $(\mathrm{VAS}=0$ ) or minimal residual pain (VAS $\leq 2)$. Over the long term, 5 additional patients underwent a second RFA due to painful recurrence. We classified all 7 patients as recurrence cases $(7 / 59=11.8 \%)$.

Painful recurrences are the product of incomplete tumor ablation [21 - 24]. The largest studies have published recurrence rates of $0-35 \%$ ( 0 Table 2). Kjar et al. showed that the rate of recurrence was significantly higher for osteoid osteomas measuring more than $10 \mathrm{~mm}$ in diameter [25]. In our study we successful treated 5 of the 7 recurrences with another round of RFA without having to switch to another treatment method (medication, surgery). For the remaining 2 recurrences, further procedure is currently being discussed.

According to Rosenthal et al., a comparison of the rates of recurrence for surgical therapy and RFA yields no significant difference (91 vs. 89\%) [26]. However, RFA proved to be superior in treating symptomatic recurrence following surgical resection (100 vs. 90\%) [27].

With regard to the safety of RFA in treating osteoid osteoma, multiple studies have shown RFA to be a safe method with a low rate of complications. The major studies on the use of RFA for osteoid osteoma presented above indicated a complication rate of only $3 \%(41 / 1217)$ with the most common complication being the appearance of skin burns [28 -35]. In our study, we recorded two major complications (soft tissue abscess, post-interventional fracture). These complications have also been reported by other authors $[25,36]$. Furthermore, one of our 59 patients experienced a minor complication in the form of a loss of sensitivity that spontaneously subsided within 2 weeks.

Due to the proximity to nervous structures, treating osteoid osteomas near the spinal column constitutes a special situation. However, multiple studies have shown that RFA is also a safe method of therapy for spinal osteoid osteomas [37, 38 . Both studies achieved absence of pain in $79 \%$ of cases following initial RFA. Nervous structures can be isolated and cooled using air or carbon dioxide (CO2), or can alternatively be displaced with glucose or sterile water [37]. If the space-occupying aspect of the osteoid osteoma results in a compression of the nerve root, then surgery is indicated for the osteoid osteoma [38].

With regard to therapy satisfaction and the subjective perception of pain, we positively established that all 53 surveyed patients were completely satisfied with RFA for the treatment of their osteoid osteoma. The patients also confirmed that they would undergo RFA at our hospital again for any potential recurrences. We assume that these results are also based on the fact that the patients became free of pain within a short time following treatment. In our opinion, the $100 \%$ patient satisfaction and the fact that all patients are currently pain-free are the strongest arguments for treating osteoid osteoma with RFA.

In the German DRG (Diagnosis-related groups) System, RFA of symptomatic osteoid osteoma (ICD-10 Code: D16.-, OPSCode: 5-789.6 „Other surgeries on the bone: destruction through radiofrequency thermoablation, percutaneous") is categorized under the collective DRG I28C („Other interventions on connective tissue"). Because OPS and DRG already cover bone drilling and the possibly necessary medical imaging, no higher classification is necessary. With an 
Table 2 Overview of the clinical results of radiofrequency ablation in symptomatic osteoid osteoma; selection criterion was study with > 20 patients; in case of multiple studies from the same institution, the most recent study or the study with the highest number of patients was selected; Studies were sorted by number of patients ( $\mathrm{N}=$ patients; $\mathrm{RFA}=$ radiofrequency ablation; $-=$ not specified $)$.

\begin{tabular}{|c|c|c|c|c|c|c|c|}
\hline Author, city, year & $\mathbf{N}$ & Method & Target temperature & Location & Initial success & $\begin{array}{l}\text { Complications } \\
\text { (absolute) }\end{array}$ & $\begin{array}{l}\text { Average follow- } \\
\text { up (in months) }\end{array}$ \\
\hline Rimondi, Bologna, 2012 [39] & 557 & RFA & $90-93^{\circ} \mathrm{C}, 4-15$ min. ${ }^{1}$ & peripheral & $96 \%$ & 5 & - \\
\hline Rosenthal, Boston, 2003 [33] & 117 & RFA & $90^{\circ} \mathrm{C}, 6 \mathrm{~min}$. & $\begin{array}{l}\text { peripheral + } \\
\text { vertebral body }\end{array}$ & $91 \%$ & 2 & $>24$ \\
\hline $\begin{array}{l}\text { Vanderschueren Leiden } 2002 \\
\text { [34] }\end{array}$ & 97 & RFA & $90^{\circ} \mathrm{C}, 4 \mathrm{~min}$. & $\begin{array}{l}\text { peripheral + } \\
\text { vertebral body }\end{array}$ & $75 \%$ & 2 & 41 \\
\hline $\begin{array}{l}\text { Rehnitz, Heidelberg, } 2012 \\
{[40,41]}\end{array}$ & 77 & RFA & $90^{\circ} \mathrm{C}, 6,5 \mathrm{~min}$. & $\begin{array}{l}\text { peripheral + } \\
\text { vertebral body }\end{array}$ & $96 \%$ & 2 & 35.5 \\
\hline Cichon, Münster, 2006 [42] & 74 & RFA & $90^{\circ} \mathrm{C}, 4-6 \mathrm{~min}$. & $\begin{array}{l}\text { peripheral + } \\
\text { vertebral body }\end{array}$ & $88 \%$ & 1 & 49.9 \\
\hline Peyser, Jerusalem, 2007 [43] & 51 & RFA & $60-90^{\circ} \mathrm{C}, 5-7 \mathrm{~min}$. & $\begin{array}{l}\text { peripheral + } \\
\text { vertebral body }\end{array}$ & $98 \%$ & 1 & 24 \\
\hline Jankharia, Mumbai, 2009 [44] & 40 & RFA & $90^{\circ} \mathrm{C}, 5 \mathrm{~min}$. & peripheral & $95 \%$ & 2 & 8 \\
\hline Hoffmann, Munich, 2010 [36] & 39 & RFA & $80-95^{\circ} \mathrm{C}, 6-8 \mathrm{~min}$. & $\begin{array}{l}\text { peripheral + } \\
\text { vertebral body }\end{array}$ & $92 \%$ & 3 & 30.5 \\
\hline Cioni, Pisa, 2004 [45] & 38 & RFA & $85-90^{\circ} \mathrm{C}, 4-5 \mathrm{~min}$. & peripheral & $79 \%$ & 2 & 35.5 \\
\hline Neumann, Salzburg, 2011 [46] & 33 & RFA & $95-100^{\circ} \mathrm{C}, 1.5 \mathrm{~min}$. & peripheral & $97 \%$ & - & 92 \\
\hline Sung, Seoul, 2009 [47] & 28 & RFA & $80-90^{\circ} \mathrm{C}, 3-9 \mathrm{~min}$. & peripheral & $82 \%$ & 1 & 41.1 \\
\hline Kjar, Melbourne, 2006 [25] & 24 & RFA & $90^{\circ} \mathrm{C}, 4 \mathrm{~min}$ & peripheral & $65 \%$ & - & 26 \\
\hline $\begin{array}{l}\text { Vanderschueren Leiden, } 2009 \\
\text { [38] }\end{array}$ & 24 & RFA & $90^{\circ} \mathrm{C}, 4 \mathrm{~min}$. & vertebral body & $79 \%$ & - & $72 \%$ \\
\hline $\begin{array}{l}\text { Ockendon, Oswestry } \\
2011[48]\end{array}$ & 23 & RFA & $90^{\circ} \mathrm{C}, 4 \mathrm{~min}$. & peripheral & $96 \%$ & - & 3.3 \\
\hline Donkol, Cairo 2008 [29] & 23 & RFA & $90^{\circ} \mathrm{C}, 4,5 \mathrm{~min}$. & peripheral & $91 \%$ & 3 & 28 \\
\hline Mylona, Athens, 2010 [49] & 23 & RFA & $80-110^{\circ} \mathrm{C}, 8-10 \mathrm{~min}$. & $\begin{array}{l}\text { peripheral + } \\
\text { vertebral body }\end{array}$ & $91 \%$ & - & - \\
\hline Ghanem, Beirut, 2003 [50] & 23 & RFA & & peripheral & $100 \%$ & 3 & 42 \\
\hline $\begin{array}{l}\text { Schmidt-D, Tübingen, } 2011 \\
\text { [51] }\end{array}$ & 23 & RFA & $60-90^{\circ} \mathrm{C}, 4-6 \mathrm{~min}$. & peripheral & $100 \%$ & 8 & 75.9 \\
\hline $\begin{array}{l}\text { Mastrantuono, Turin, } 2005 \\
\text { [52] }\end{array}$ & 21 & RFA & $85-90^{\circ} \mathrm{C}$ & peripheral & $100 \%$ & - & 11.1 \\
\hline $\begin{array}{l}\text { Kyriakopoulos, Athens, } 2007 \\
\text { [53] }\end{array}$ & 21 & RFA & $90^{\circ} \mathrm{C}, 3 \times 2 \mathrm{~min}$. & peripheral & $100 \%$ & - & 29 \\
\hline Total & 1356 & & & & $\begin{array}{l}92 \% \\
(1247 / 1356)\end{array}$ & $2,9 \%(35 / 1187)$ & \\
\hline
\end{tabular}

${ }^{1}$ A group ( $\mathrm{N}=68$ ) with $90-93^{\circ} \mathrm{C}$ for 4 minutes and a second group $(\mathrm{N}=489)$ with $60^{\circ} \mathrm{C}$ for 2 minutes followed by ablation with $90-93^{\circ} \mathrm{C}$ for $14-15$ minutes.

effective cost weight of 0.844 (2012, only 0.792 in 2013) the hospital receives a revenue $€ 2494$ at a state-specific base rate of $€ 2955$ in 2012, meaning that the DRG revenue is significantly lower compared to that of RFA of liver or kidney tumors. While the RFA needles for treating osteoid osteoma are somewhat less expensive, costing approximately $€ 800$ - 900 (liver/kidney RFA needles cost approximately $€ 1500$ ), the additional expenses for general anesthesia must be taken into consideration. Another disadvantage of this classification in the DRG system is that the minimum length of stay for this DRG is two days, meaning that early discharge would entail considerable deductions. It is currently not possible to bill patients carrying public health insurance for outpatient surgery.

The key limitation of this study is its retrospective design that hinders the uniform collection of data.

Despite the limitations, we can conclude that RFA is a safe, minimally invasive therapy option for the treatment of osteoid osteoma with a high initial success rate and a low rate of recurrence. Patients experiencing a painful recurrence of osteoid osteoma should be offered the option of a second radiofrequency ablation. Long-term patient satisfaction following RFA of osteoid osteomas is high.

\section{Acknowledgement}

$\boldsymbol{\nabla}$ This manuscript is dedicated to Professor Bernd Hamm for his 60th birthday.

\section{Literatur}

1 Jaffe HL. Osteoid osteoma: a benign osteoblastic tumor composed of osteoid and atypical bone. Arch Surg 1935; 31: 709-728

2 Mungo DV, Zhang X, O'Keefe RJ et al. COX-1 and COX-2 expression in osteoid osteomas. J Orthop Res 2002; 20: 159-162

3 Bloem JL, Kroon HM. Osseous lesions. Radiologic clinics of North America 1993; 31: 261-278

4 Kneisl JS, Simon MA. Medical management compared with operative treatment for osteoid-osteoma. J Bone Joint Surg Am 1992; 74: 179185

5 Moberg E. The natural course of osteoid osteoma. J Bone Joint Surg Am 1951; 33: $166-170$

6 Ilyas I, Younge DA. Medical management of osteoid osteoma. Can J Surg 2002; 45: $435-437$ 
7 Rosenthal DI, Alexander A, Rosenberg AE et al. Ablation of osteoid osteomas with a percutaneously placed electrode: a new procedure. Radiology 1992; 183: 29-33

8 Cantwell CP, Obyrne J, Eustace S. Current trends in treatment of osteoid osteoma with an emphasis on radiofrequency ablation. Eur Radiol 2004; 14: 607-617

9 Liu PT, Kujak JL, Roberts CC et al. The vascular groove sign: a new CT finding associated with osteoid osteomas. Am J Roentgenol American journal of roentgenology 2011; 196: 168-173

10 Yaniv G, Shabshin N, Sharon M et al. Osteoid osteoma-the CT vessel sign. Skeletal Radiol 2011; 40: 1311 - 1314

11 Omary RA, Bettmann MA, Cardella JF et al. Quality improvement guidelines for the reporting and archiving of interventional radiology procedures. J Vasc Interv Radiol 2003; 14: S293 - S295

12 Sacks D, McClenny TE, Cardella JF et al. Society of Interventional Radiology clinical practice guidelines. J Vasc Interv Radiol 2003; 14: S199S202

13 Freiberger RH, Loitman BS, Helpern M et al. Osteoid osteoma; a report on 80 cases. The American journal of roentgenology, radium therapy, and nuclear medicine 1959; 82: 194-205

14 Campanacci M, Ruggieri P, Gasbarrini A et al. Osteoid osteoma. Direct visual identification and intralesional excision of the nidus with minimal removal of bone. J Bone Joint Surg Br 1999; 81: 814-820

15 Sluga M, Windhager R, Pfeiffer $M$ et al. Peripheral osteoid osteoma. Is there still a place for traditional surgery? J Bone Joint Surg $\mathrm{Br} 2002$; 84: $249-251$

16 Ward WG, Eckardt JJ, Shayestehfar S et al. Osteoid osteoma diagnosis and management with low morbidity. Clin Orthop Relat Res 1993: $229-235$

17 Yildiz Y, Bayrakci K, Altay M et al. Osteoid osteoma: the results of surgical treatment. Int Orthop 2001; 25: 119-122

18 Kohler R, Rubini J, Postec F et al. Treatment of osteoid osteoma by CTcontrolled percutaneous drill resection. Apropos of 27 cases. Rev Chir Orthop Reparatrice Appar Mot 1995; 81: 317 - 325

19 Parlier-Cuau C, Champsaur P, Nizard $R$ et al. Percutaneous removal of osteoid osteoma. Radiologic clinics of North America 1998; 36: 559566

20 Roderer G, Nelitz M, Puhl W et al. Minimalinvasive Therapie bei Osteoidosteom. Z Orthop Ihre Grenzgeb 2004; 142: 456-461

21 Greenspan A. Sklettradiologie: Orthopädie, Traumatologie, Rheumatologie, Onkologie. 3 ed. München: Urban \& Fischer Verlag/Elsevier $\mathrm{GmbH} ; 2007$

22 Lee DH, Malawer MM. Staging and treatment of primary and persistent (recurrent) osteoid osteoma. Evaluation of intraoperative nuclear scanning, tetracycline fluorescence, and tomography. Clin Orthop Relat Res 1992: 229-238

23 Mahnken AH, Bruners P, Delbruck $H$ et al. Radiofrequency ablation of osteoid osteoma: initial experience with a new monopolar ablation device. Cardiovasc Intervent Radiol 2011; 34: 579-584

24 Norman A. Persistence or recurrence of pain: a sign of surgical failure is osteoid-osteoma. Clin Orthop Relat Res 1978: 263 - 266

25 Kjar RA, Powell GJ, Schilcht SM et al. Percutaneous radiofrequency ablation for osteoid osteoma: experience with a new treatment. Med J Aust 2006; 184: 563 - 565

26 Rosenthal DI, Hornicek FJ, Wolfe MW et al. Percutaneous radiofrequency coagulation of osteoid osteoma compared with operative treatment. J Bone Joint Surg Am 1998; 80: 815 -821

27 Rosenthal DI, Springfield DS, Gebhardt MC et al. Osteoid osteoma: percutaneous radio-frequency ablation. Radiology 1995; 197: 451 - 454

28 Barei DP, Moreau G, Scarborough MT et al. Percutaneous radiofrequency ablation of osteoid osteoma. Clin Orthop 2000: 115-124

29 Donkol RH, Al-Nammi A, Moghazi K. Efficacy of percutaneous radiofrequency ablation of osteoid osteoma in children. Pediatric radiology 2008; 38: $180-185$

30 Lindner NJ, Ozaki T, Roedl R et al. Percutaneous radiofrequency ablation in osteoid osteoma. J Bone Joint Surg Br 2001; 83: 391 - 396

31 Osti OL, Sebben $R$. High-frequency radio-wave ablation of osteoid osteoma in the lumbar spine. Eur Spine J 1998; 7: 422 - 425
32 Rimondi E, Bianchi G, Malaguti MC et al. Radiofrequency thermoablation of primary non-spinal osteoid osteoma: optimization of the procedure. European radiology 2005; 15: 1393 -1399

33 Rosenthal DI, Hornicek FJ, Torriani M et al. Osteoid osteoma: percutaneous treatment with radiofrequency energy. Radiology 2003; 229: $171-175$

34 Vanderschueren GM, Taminiau AH, Obermann WR et al. Osteoid osteoma: clinical results with thermocoagulation. Radiology 2002; 224: $82-86$

35 Woertler K, Vestring T, Boettner F et al. Osteoid osteoma: CT-guided percutaneous radiofrequency ablation and follow-up in 47 patients. J Vasc Interv Radiol 2001; 12: 717-722

36 Hoffmann RT, Jakobs TF, Kubisch $\mathrm{CH}$ et al. Radiofrequency ablation in the treatment of osteoid osteoma-5-year experience. Eur J Radiol 2010; 73: $374-379$

37 Rybak LD, Gangi A, Buy X et al. Thermal ablation of spinal osteoid osteomas close to neural elements: technical considerations. Am J Roentgenol American journal of roentgenology 2010; 195: W293 - W298

38 Vanderschueren GM, Obermann WR, Dijkstra SP et al. Radiofrequency ablation of spinal osteoid osteoma: clinical outcome. Spine 2009; 34: $901-904$

39 Rimondi E, Mavrogenis AF, Rossi G et al. Radiofrequency ablation for non-spinal osteoid osteomas in 557 patients. Eur Radiol 2012; 22: $181-188$

40 Omlor G, Merle C, Lehner B et al. CT-guided percutaneous radiofrequency ablation in osteoid osteoma: re-assessments of results with optimized technique and possible pain patterns in mid-term follow-up. Fortschr Röntgenstr 2012; 184: 333 -339

41 Rehnitz C, Sprengel SD, Lehner B et al. CT-guided radiofrequency ablation of osteoid osteoma and osteoblastoma: clinical success and longterm follow up in 77 patients. Eur J Radiol 2012; 81: 3426-3434

42 Cichon CW, Bottner F, Rodl R et al. Die minimalinvasive Therapie beim Osteoidosteom mittels CT-gesteuerter Thermokoagulation im Langzeitverlauf. Zeitschrift fur Orthopadie und ihre Grenzgebiete 2006; 144: $332-337$

43 Peyser A, Applbaum Y, Simanovsky $N$ et al. CT-guided radiofrequency ablation of pediatric osteoid osteoma utilizing a water-cooled tip. Ann Surg Oncol 2009; 16: 2856-2861

44 Jankharia $B$, Burute $N$. Percutaneous radiofrequency ablation for osteoid osteoma: How we do it. The Indian journal of radiology \& imaging 2009; 19: $36-42$

45 Cioni R, Armillotta N, Bargellini I et al. CT-guided radiofrequency ablation of osteoid osteoma: long-term results. Eur Radiol 2004; 14: $1203-1208$

46 Neumann D, Berka H, Dorn $U$ et al. Follow-up of thirty-three computed-tomography-guided percutaneous radiofrequency thermoablations of osteoid osteoma. Int Orthop 2011; 36: 811 - 815

47 Sung KS, Seo JG, Shim JS et al. Computed-tomography-guided percutaneous radiofrequency thermoablation for the treatment of osteoid osteoma-2 to 5 years follow-up. Int Orthop 2009; 33: 215-218

48 Ockendon M, Gregory JJ, Cribb GL et al. Osteoid osteoma: can impedance levels in radiofrequency thermocoagulation predict recurrence? Radiology research and practice 2011; 2011: 753502

49 Mylona S, Patsoura S, Galani P et al. Osteoid osteomas in common and in technically challenging locations treated with computed tomography-guided percutaneous radiofrequency ablation. Skeletal radiology 2010; 39: 443 - 449

50 Ghanem I. The management of osteoid osteoma: updates and controversies. Curr Opin Pediatr 2006; 18: 36-41

51 Schmidt D, Clasen S, Schaefer JF et al. CT-gesteuerte Radiofrequenz(RF)Ablation von Osteoidosteomen: klinische Langzeitergebnisse. Fortschr Röntgenstr 2011; 183: 381 - 387

52 Mastrantuono D, Martorano D, Verna V et al. Osteoid osteoma: our experience using radio-frequency (RF) treatment. Radiol Med 2005; 109 : $220-228$

53 Kyriakopoulos KK, Mavrogenis AF, Pappas J et al. Percutaneous computed tomography-guided radiofrequency ablation of osteoid osteomas. Eur J Orthop Surg Traumatol 2007; 17: 8 